УДК 338.488.2: 640.43(477)

DOI: https://doi.org/10.37320/2415-3583/14.7

Коваленко Г.В. кандидат економічних наук, старший викладач, Миколаӥвський начіональний аграрний університет ORCID: https://orcid.org/0000-0002-7306-4270

Поточилова I.C. аспірант, Миколаӥвський начіональний аграрний університет ORCID: https://orcid.org/0000-0001-7785-4053

\title{
ОСНОВНІ ТРЕНДИ РОЗВИТКУ СФЕРИ РЕСТОРАННИХ ПОСЛУГ МИКОЛАЇВСЬКОЇ ОБЛАСТІ
}

Окреслено важливість сфери ресторанного господарства для економіки країни. Воно вирішує низку соиіальних проблем, зокрема виступає однією з ланок розподілу матеріальних благ у суспільстві і сприяє рачіональному використанню харчових ресурсів держави, поліпшенню здоров'я людей, зростанню продуктивності прачі. Галузь ресторанного господарства є висококонкурентною сферою з високою окупністю і високими ризиками. Тому підприємствам ресторанної галузі постійно необхідно стежсти за новими трендами у своїи галузі $і$ вміти оперативно підлаштовуватися під них. Зосереджено увагу на актуальних світових тенденціях розвитку закладів харчування. Виділені основні тренди, які впливають на заклади сфери ресторанного бізнесу, такі як: створення тематичних ресторанів; надання послуги з кейтерингу; розвиток франчайзингу; створення креативних просторів; використання інноваційних інтернет-технологій. Проведено типізацію закладів підприємств ресторанного господарства м. Миколаєва.

Ключові слова: ресторанній бізнес, тенденції, послуги, інноваційні технології, тренди, франшиза.

Постановка проблеми. Сфера ресторанних послуг як частина індустрії гостинності є однією з найбільш перспективних та динамічно зростаючих серед галузей економіки. За статистикою, середній обіг коштів, вкладених у ресторан, відбувається в 5-6 разів швидше, ніж інвестицій, вкладених, наприклад, у магазин одягу. Кожного року попит на послуги закладів харчування тільки збільшується.

Для успішного ведення ресторанної справи потрібно постійно бути в курсі світових тенденцій у 
цій сфері. Адже тренди постійно оновлюються, і щоб не втратити клієнта, необхідно використовувати весь спектр інноваційних технологій у своїй роботі.

Реалії сьогодення вимагають від українських підприємств ресторанного господарства значної інноваційної активності в умовах загострення конкурентної боротьби. Цьому сприятиме застосування прогресивних форм і методів обслуговування, використання інтернет-технологій, модернізація обладнання, добір професійного персоналу тощо.

Аналіз останніх досліджень і публікацій. Окремі фундаментальні аспекти розвитку готельно-ресторанних підприємств висвітлено у працях зарубіжних та вітчизняних учених, серед яких особливо заслуговують на увагу наукові праці, присвячені особливостям розвитку готельно-ресторанного бізнесу в Україні. Це праці О. Борисова [1], М. Гінда [2], О. Кравченко [3], Г. Нагорняк [4], О. Чумак [5]. Тенденціям в обслуговуванні клієнтів присвятили свої дослідження I. Верезомська [6], Л. Гірняк [7], О. Крупський [8], та інші провідні вчені.

У роботах цих учених розглядаються як основи організації роботи закладів ресторанного господарства, так і нові моделі обслуговування споживачів. Однак зі швидкими темпами розвитку інноваційних винаходів, технологій у сучасному світі ці дослідження вимагають подальшого системного розгляду.

Мета статті полягає у виявлені ключових факторів, що впливають на тенденції розвитку ресторанного господарства України та м. Миколаєва. Для реалізації цієї мети у дослідженні проаналізовано основні тенденції, які впливають на розвиток закладів ресторанного господарства; проведено типізацію закладів підприємств ресторанного господарства м. Миколаєва.

Виклад основного матеріалу дослідження. Сфера ресторанного бізнесу характеризується наявністю особливостей соціального, галузевого та організаційноекономічного характеру. До соціальних особливостей належать: залежність режиму роботи підприємств ресторанного господарства від режиму роботи організацій, які ними обслуговуються; залежність попиту на кулінарну продукцію від часу доби, днів тижня, пори року; залежність асортименту продукції від особливостей контингенту, що ним обслуговується (професійного, вікового, національного складу); залежність від рівня доходів населення й цін на кулінарну продукцію; залежність від компактності (щільності) населених пунктів, наявності інших підприємств ресторанного господарства та продуктових магазинів.

До галузевої особливості належить сам процес діяльності закладів ресторанного господарства, що одночасно виконують три взаємопов'язані і взаємозалежні функції: виробництво продукції; реалізацію цієї продукції; організацію ії споживання. Одночасне виконання одразу трьох функцій виокремлює ресторанне господарство в окрему галузь, тому що більшість підприємств інших галузей обмежуються виконанням лише однієї, максимум двох функцій.

Ресторанне господарство тісно пов'язане 3 розвитком всієї економіки держави і є способом вирішення важливих соціальних проблем, воно є однією з ланок розподілу матеріальних благ у суспільстві і сприяє раціональному використанню харчових ресурсів кра- їни. Заклади ресторанного господарства як суб'єкт економічної діяльності сприяють поліпшенню здоров'я людей, зростанню продуктивності праці, раціональному використанням харчових ресурсів, зменшенню часу на приготування їжі у домашніх умовах.

Ринок ресторанних послуг характеризується нетривалим життєвим циклом (1-3 роки) і високим ступенем ризику (3-4 місце). Тому підприємствам ресторанної галузі постійно необхідно стежити за новими трендами у своїй галузі і вміти оперативно підлаштовуватись під них. Для того, щоб вижити і розвиватися в конкурентному ринковому середовищі, ринкові суб'єкти повинні вміти формувати власні конкурентні переваги, які здебільшого досягаються завдяки впровадженню інновацій [9].

Згідно 3 дослідженнями Міжнародної асоціації готелів і ресторанів, у світі функціонує понад 8 млн підприємств харчування різних типів, які забезпечують робочими місцями близько 50 млн осіб. Щорічні доходи підприємств цієї сфери перевищують700 млрд дол.

Одна $з$ основних тенденцій, яка є характерною як для світового так і для українського ринку ресторанних послуг, - це створення тематичних ресторанів. Зокрема, на основі кулінарних традицій різних країн. Наприклад, ресторани України пропонують своїм гостям страви кухонь більш ніж тридцяти держав світу. Зазвичай у таких закладах обмежена кількість страв, але вони роблять акцент на створенні настрою та певної атмосфери.

Ще один напрям обслуговування, який давно використовується за кордоном, але тільки набирає популярності в Україні, - «catering» - надання послуг 3 обслуговування споживачів поза межами залів закладів ресторанного господарства (в офісах, установах, на природі, на дому). Послуги 3 «кейтерингу» здійснюють не тільки заклади ресторанного бізнесу, а й фірми, створені на базах ресторанів, і заклади харчування при готельних комплексах, у тому числі з різною формою власності. Крім того, все популярнішим стає акцент на здоровому харчуванні, (у приготуванні страв використовується екологічно чиста сировина без генно-модифікованих продуктів).

Незмінною популярністю у всьому світі користуються мережеві ресторани фаст-фуду (McDonald's, Pizza Hut, Domino, Little Geasar, Sizzler, Redlobster, Subway). В Україні перший ресторан швидкого харчування «McDonald's» було відкрито в 1997 році. 3 нього бере початок франчайзингова схема господарювання, до цього місцева галузь закладів швидкого харчування була представлена лише їдальнями і кафетеріями радянського типу. Франчайзинг - під'єднання до ресторанного ланцюга закладів, які належать різним власникам, при цьому договір визначає зобов'язання між ними. Основною перешкодою для розвитку франчайзингу в Україні є недостатнє визнання прав інтелектуальної власності. Більшість іноземних мереж ресторанів швидкого обслуговування усе ще не приходять в Україну через відсутність не лише законодавства в галузі франчайзингу, а й незадовільного загального ділового клімату.

Наприклад, у місті Миколаєві набуває популярності створення бізнесу за допомогою франчайзингу (таблиця 1). За останній рік збільшилася кількість закладів які приєдналися до українських і світових 
Таблиця 1 - Торгові марки, представлені у сфері ресторанного бізнесу м. Миколаїв

\begin{tabular}{|c|c|c|c|c|}
\hline \multirow{2}{*}{$\begin{array}{c}\text { Умови отримання } \\
\text { франшизи }\end{array}$} & \multicolumn{4}{|c|}{ Назви торгових марок } \\
\hline & Doshi Doshi & Суши Wok & Lviv Croissants & Pizza Celentano Ristorante \\
\hline $\begin{array}{l}\text { Паушальний } \\
\text { внесок }\end{array}$ & від 4000\$ & $4500 \$$ & $10000 \$$ & $10000-12000 €$ \\
\hline $\begin{array}{l}\text { Період окупності / } \\
\text { місяців }\end{array}$ & від 12 & від 6 & від 12 до 24 & $24-36$ \\
\hline Інвестиції & Від $8000 \$$ & Від $16000 \$$ & Від $30000-70000 \$$ & Від $170000 €$ \\
\hline На ринку & 32010 p. & $32011 \mathrm{p}$ & $32015 \mathrm{p}$ & з 1999 p. \\
\hline $\begin{array}{l}\text { Площа } \\
\text { приміщення }\end{array}$ & від $25 \mathrm{~m}^{2}$ & $15-70 \mathrm{M}^{2}$ & $30-150 \mathrm{M}^{2}$ & $\begin{array}{c}\text { від } 200 \text { м²; для фуд-корту } \\
\text { від } 70 \text { м². }^{2}\end{array}$ \\
\hline Штат персоналу & від 2 чоловік & від 2 чоловік & - & $\begin{array}{c}\text { від } 30 \text { чоловік, } \\
\text { від } 16 \text { для фуд-корту }\end{array}$ \\
\hline Роялті & 5,0\% від обороту в місяць & $3,5 \%$ & $\begin{array}{c}\text { 3\% від загального } \\
\text { виторгу в місяць }\end{array}$ & 1,5 \% від обороту \\
\hline Робота в форматах & $\begin{array}{l}\text { Quickly here and now take } \\
\text { away }\end{array}$ & Take away & $\begin{array}{c}\text { Швидке } \\
\text { приготування } \\
\text { "з-під ножа" }\end{array}$ & Піца та вино \\
\hline $\begin{array}{l}\text { Торгівля online } \\
\text { i offline }\end{array}$ & + & + & + & + \\
\hline Доставка & + & + & + & + \\
\hline $\begin{array}{l}\text { Кількість у } \\
\text { м. Миколаїв }\end{array}$ & 3 & 4 & 1 & 6 \\
\hline $\begin{array}{l}\text { Відпрацьована } \\
\text { бізнес-модель }\end{array}$ & Присутність в 4 містах & $\begin{array}{c}700+\text { відкритих } \\
\text { закладів } \\
\text { Присутність в } 5 \\
\text { країнах }\end{array}$ & $\begin{array}{c}\text { Присутність в } 40 \\
\text { містах України }\end{array}$ & 182 заклади \\
\hline
\end{tabular}

Джерело: складено автором на основі джерела [12; 13]

мережевих закладів харчування. Нині у місті представлені такі торгові марки, як: McDonald's - 1 заклад, Pizza Celentano Ristorante - 6 закладів, Doshi Doshi 3 заклади, Суши Wok - 4 заклади, Aroma Kava - 5 закладів, Франс.уа, - 2 заклади, Grill Pab - 1 заклад, Mafia 1 заклад, Lviv Croissants - 1 заклад, Крила - 1 заклад, New York Street Pizza - 1 заклад. А також створюються власні ланцюгові торгові марки, як, наприклад, мережа кофеєн «Coffee Go», які починали працювати в 2012 році з формату «кава 3 собою», а в минулому році вже почали відкривати кафе 3 повноцінним меню.

Актуальним стає напрям створення фуд-кортів (ресторанних двориків) у великих торговельних центрах, вони користуються популярністю майже у всіх категорій відвідувачів.

Кілька останніх років набирає популярність формат «open kitchen» («відкрита кухня»), коли відвідувачі можуть спостерігати за процесом приготування, оцінювати якість продуктів i рівень майстерності кухаря. Оскільки клієнти бачать весь робочий процес зсередини, вони не сумніваються в свіжості продуктів і якості роботи персоналу. До того ж, очікування в ресторані проходить набагато цікавіше, ніж просто вид із вікна або екран телевізора [10].

3'являються заклади, які належать до категорії креативних просторів («коворкінг»). Вони здебільшого розташовуються в центрі міста або в офісних центрах. Основна концепція таких закладів - безкоштовно все, крім часу. Ці заклади працюють за системою «все включено» (відвідувач платить за час, який він проводить у приміщені), вони орієнтовані на фрілансерів, стартаперів, ІТ-підприємців та маркетологів. Коворкінг - це модель роботи, коли працівники залишаються віль- ними і незалежними та використовують вільний простір для своєї діяльності. Креативні простори і коворкінги являють собою свого роду культурно-освітні кластери, які поєднують у собі кафе, офісні та освітні центри, магазини, велопрокати, кінозали, конференцзали, дизайн-бутики, шоу-руми, лекторії і майданчики для тусовки тощо [11].

I найактуальнішім трендом 2020 року у ресторанному обслуговувані стало використання інтернет-технологій для прийому й оплати замовлення. Підприємства, які мали такі сервіси, були у більш вигідному становищі, ніж ті, яким довелося створювати їх у форс-мажорних умовах. Якщо раніше ними користувалася невелика кількість підприємств, то зараз майже усі заклади харчування мають онлайн-сервіси (інтернет-сторінки закладів у соціальних мережах, додатки для смартфонів, боти тощо). Серед таких інноваційних технологій в готельно-ресторанному господарстві особливим попитом користується: застосування інтерактивного (електронного) меню, екрану-планшету на столах, сенсорного дисплею, застосування QR-коду, автоматизація та інформатизація процесів на підприємствах, використання web-i телекомунікаційних технологій тощо [4].

У місті Миколаєві діють загальноміські сайти (Mixfood, Eda.ua.) і додатки (Glovo) $з$ доставки, а також у закладів харчування є власні служби доставки. Крім того, діють онлайн-піцерія Nikolaev-pizza, онлайн-ресторани здорового харчування Smilefood, FoodEx.

Вирішальним фактором поліпшення роботи підприємств ресторанного господарства $є$ якісна робота персоналу закладу. Підвищенню якості обслуговування сприяє висока майстерність і рівень професійної підго- 


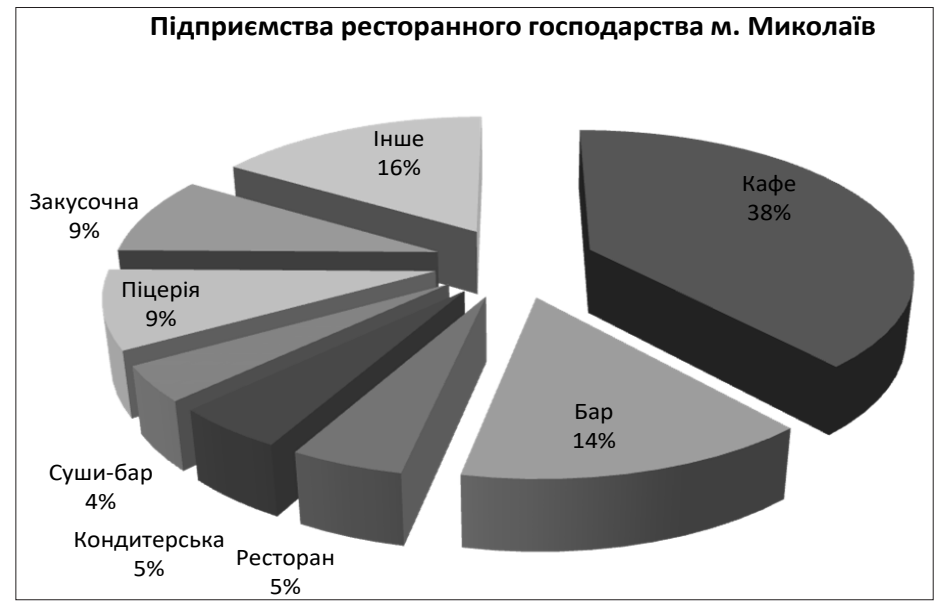

Рисунок 1 - Підприємства ресторанного господарства м. Миколаїв

Джерело: складено авторами на основі [14]

товки працівників, який досягається за рахунок чіткої системи підготовки і підвищення кваліфікації кадрів, організації тренінгу персоналу, професійних конкурсів та обліку індивідуальних можливостей працівників. Культура обслуговування значно підвищує привабливість підприємства готельно-ресторанного бізнесу та сприяє зміцненню рівня його конкурентоспроможності.

У місті Миколаєві налічується 254 підприємства ресторанного господарства, 3 них найбільш розповсюдженим типом закладів $\epsilon$ кафе -98 закладів різної форми власності (рис. 1). На другому місці за кількістю - заклади типу «бар» (37 закладів). Наступні за кількістю - типи закладів «піцерія» і «закусочна», їх по 22 заклади. Також порівну налічується ресторанів i кондитерських - по 12 закладів. Найменш численним типом закладів, представлених у місті, є «суші-бар» 10 закладів. До іншого включені такі типи закладів, як кафетерій, їдальня та буфет - загалом 41 заклад.

Отже, до актуальних трендів розвитку сфери ресторанного бізнесу можна віднести: тенденції до спеці- алізації ресторанної пропозиції; створення міжнародних ресторанних ланцюгів; розвиток мережі франчайзингу; впровадження в індустрію гостинності нових комп'ютерних технологій. Останнім часом поряд із традиційними повносервісними ресторанами з'являється все більше спеціалізованих підприємств зі скороченим набором послуг і страв.

В Україні ресторанна справа ще не набула особливої популярності і перебуває лише на стадії зародження, у тому числі внаслідок низького рівня доходів більшої частини населення України. Загалом динамічний розвиток цього виду економічної діяльності зумовлює появу закладів ресторанного господарства різних типів і цінових категорій, що дає споживачам можливість вибирати такий заклад ресторанної сфери, що найбільш підходить для них за всіма критеріями [3, с. 106].

Висновки. Отже, тенденції на ринку у сфері ресторанного господарства досить тісно пов'язані з рівнем соціально-економічного розвитку держави, динамікою доходів та структурою витрат населення, зміною структури попиту та пропозиції, рівнем автоматизації бізнес-процесів. Зміна споживчих запитів приводить до необхідності розширення спектру додаткових послуг, що сприятиме найбільш повному задоволенню потреб клієнтів, а отже, забезпечить підвищення рівня конкурентоспроможності підприємства ресторанного господарства та зміцнення його конкурентної позиції на ринку.

Встановлено, що найбільш популярними підприємствами ресторанного господарства м. Миколаєва $є$ кафе та бари. Збільшується кількість закладів, які приєднуються до франчайзингових ланцюгів. Але слід відзначити, що основною перешкодою для розвитку франчайзингу в Україні загалом та в Миколаївській області $є$ недостатнє визнання прав інтелектуальної власності.

Зауважимо, що ресторанний бізнес є одним із найбільш розповсюджених видів малого бізнесу, який динамічно розвивається та має гарні перспективи для подальшого розвитку в Миколаївській області.

Список використаних джерел:

1. Борисова О.В. Тенденції розвитку готельно-ресторанного бізнесу в Україні. Економічна стратегія $і$ перспективи розвитку сфери торгівлі та послуг. 2012. Вип. 1 (2). С. 331-338.

2. Гінда М.І. Тенденції розвитку ресторанного господарства. Збірник матеріалів Всеукраїнської науково-практичної конференції "Актуальні проблеми економіки та управління в умовах системної кризи" (м. Львів, 29.11.2016 р.). Львів : МАУП, 2016. Ч. 1. C. 301-306.

3. Kravchenko O.M., Sokoly I.I. Development tendencies of Ukrainian Restaurant Industry. Wirtschaft und Management: Theorie und Praxis: Sammelwerk der wissenschaftlichen Artikel. Vol. 1. Verlag SWGimex GmbH, Nurnberg, Deutschland, 2014. C. $105-110$.

4. Нагорняк Г., Малюта Л., Мельник Л., Шерстюк Р. Організаційно-економічні засади розвитку інноваційного процесу вітчизняних закладів готельно-ресторанної сфери в туристичному контексті. Соиіально-економічні проблеми і держава. 2017. Вип. 1 (16). С. 148-158. URL: http://sepd.tntu.edu.ua/images/stories/pdf/2017/17nhsvtk.pdf (дата звернення: 18.09.2020).

5. Чумак О.В., Андрющенко І.С. Аналіз стану й оцінка тенденцій показників розвитку підприємств ресторанного господарства. Бізнес-інформ. 2014. № 12. С. 307-313.

6. Верезомська І.Г. Формування корпоративної культури та імідж готельного підприємства. Науковий вісник Полтавського університету економіки і торгівлі. Серія: Економічні науки. 2011. № 6 (2). С. 136-140.

7. Гірняк Л.І., Сопіга В.Б. Формування культури та якості обслуговування у готельно-ресторанних підприємствах. Науковий вісник Ужгородського національного університету. Серія: Міжнародні економічні відносини та світове господарство. Ужгород, 2018. Вип. 21. Ч 1. С. 50-55.

8. Крупський О.П. Організаційна культура туристичного підприємства як індикатор його інноваційного потенціалу. Бізнес інформ. 2014. № 9. С. 200-204.

9. Поплавський М.М. Готельно-ресторанний сервіс : навчальний посібник для студентів вищих навчальних закладів. Київ : Макрос, 2011. 240 с.

10. Прилепа Н.В. Соколюк Г.О. Інноваційні технології у сфері ресторанного бізнесу. Вісник Хмельницького національного університету. Економічні науки. 2014. № 4. Т. 2. С. 162-164. 
11. Портал гостиничного и ресторанного бизнеса. URL: http://prohotelia.com.ua/ (дата звернення: 22.09.2020)

12. BizRating. Продажа бизнеса и франшиз. URL: http://bizrating.com.ua/franch/ (дата звернення: 23.09.2020)

13. Greensidea. Ресторанний бізнес. URL: https://greens-idea.com/franchises/restorannyij-biznes/ (дата звернення: 23.09.2020)

14. Миколаївська міська рада Офіційний портал. Дислокація підприємств ресторанного господарства. URL: https://mkrada.gov.ua/content/restorani-bari-kafe-nichni-klubi.html (дата звернення: 22.09.2020)

\section{References:}

1. Borysova O.V. (2012) Tendentsiyi rozvytku hotelno-restorannoho biznesu v Ukrayini [Trends in the development of the hotel and restaurant business in Ukraine]. Ekonomichna stratehiya i perspektyvy rozvytku sfery torhivli ta posluh, no. 1(2), pp. 331-338.

2. Hinda M.I. (2016) Tendentsii rozvytku restorannoho hospodarstva [Trends in the development of the restaurant industry]. Zbirnyk materialiv Vseukrainskoi naukovo-praktychnoi konferentsii "Aktualni problemy ekonomiky ta upravlinnia v umovakh systemnoi kryzy", vol. 1, pp. 301-306.

3. Kravchenko O.M., Sokoly I.I. (2014) Development tendencies of Ukrainian Restaurant Industry. Wirtschaft und Management: Theorie und Praxis: Sammelwerk der wissenschaftlichen Artikel, Verlag SWG imex GmbH, Nurnberg. Deutschland, vol. 1, pp. 105 - 110.

4. Nahorniak H., Maluta L., Melnyk, L., Sherstiuk R. (2017) Orhanizatsiinoekonomichni zasady rozvytku innovatsiinoho protsesu vitchyznianykh zakladiv hotelno-restorannoi sfery v turystychnomu konteksti [Organizational and economic principles of innovative development processes of national hotel and restaurant business structures in the tourism context]. Socio-Economic Problems and the State, no. 16 (1), pp. 148-158.

5. Chumak O.V., Andryushchenko I.S. (2014) Analiz stanu y otsinka tendentsiy pokaznykiv rozvytku pidpryyemstv restorannoho hospodarstva [Analysis of the state and assessment of trends in the development indicators of restaurant enterprises]. Biznes Inform, no. 12. pp. 307-313.

6. Verezomska I.H. (2011) Formuvannya korporatyvnoyi kul'tury ta imidzh hotel'noho pidpryyemstva [Formation of corporate culture and image of a hotel enterprise]. Naukovyy visnyk Poltavskoho universytetu ekonomiky $i$ torhivli. Seriya: Ekonomichni nauky, no. 6 (2), pp. 136-140.

7. Hirnyak L.I., Sopiha V. B. (2018) Formuvannya kultury ta yakosti obsluhovuvannya u hotel'no-restorannykh pidpryyemstvakh [Formation of culture and quality of service in hotel and restaurant enterprises]. Naukovyy visnyk Uzhhorodskoho natsiona'noho universytetu. Seriya: Mizhnarodni ekonomichni vidnosyny ta svitove hospodarstvo. Uzhhorod, vol. 21. 1, pp. 50-55.

8. Krups'kyy O.P. (2014) Orhanizatsiyna kultura turystychnoho pidpryyemstva yak indykator yoho innovatsiynoho potentsialu [Organizational culture of a tourist enterprise as an indicator of its innovative potential]. Biznes inform, no. 9, pp. 200-204.

9. Poplavs'kyj M.M. (2011) Hotelno-restorannyj servis [Hotel and restaurant service]. Kyiv : Makros. (in Ukrainian)

10. Prylepa N.V. Sokolyuk H.O. (2014) Innovatsiyni tekhnolohiyi u sferi restorannoho biznesu [Innovative technologies in the restaurant business]. Visnyk Khmelnytskoho natsionalnoho universytetu. Ekonomichni nauky, no. 4, vol. 2, pp. $162-164$.

11. Portal hostynychnoho y restorannoho byznesa. Available at: http://prohotelia.com.ua/ (accessed 22 September 2020).

12. BizRating. Prodazha byznesa y franshyz. Available at: http://bizrating.com.ua/franch/ (accessed 23 September 2020).

13. Greensidea. Restorannyy biznes. Available at: https://greens-idea.com/franchises/restorannyij-biznes/ (accessed 23 September 2020).

14. Mykolayivska miska rada Ofitsiynyy portal. Dyslokatsiya pidpryyemstv restorannoho hospodarstva. Available at: https://mkrada.gov.ua/content/restorani-bari-kafe-nichni-klubi.html (accessed 22 September 2020).

\section{Kovalenko Hanna, Potochylova Iryna} Mykolayiv National Agrarian University

\section{MAIN TRENDS OF DEVELOPMENT OF RESTAURANT SERVICES OF MYKOLAYIV REGION}

The restaurant services, as part of the hospitality industry, is one of the most promising and dynamically growing sectors of the economy. Prosperous restaurant business needs to be constantly aware of global trends in this area. After all, trends are frequently updated, and in order not to lose a client, you need to use the full range of innovative technologies in your work. The realities of today require significant innovation activity from Ukrainian restaurant enterprises in the context of increased competition. The purpose of the article is to identify the key factors influencing the development trends of the restaurant industry in Ukraine and Mykolayiv. To achieve this goal, the study analyzes the trends that affect the development of restaurants; typification of establishments of the enterprises of restaurant economy of Mykolayiv is carried out. Trends in the market in the restaurant sector are quite closely related to the level of socioeconomic development of the state, the dynamics of income and expenditure structure of the population, changes in the structure of supply and demand, and the level of automation of business processes. Changes in consumer demands lead to the need to expand the range of additional services, which will contribute to the most complete satisfaction of customer needs, and therefore, will increase the level of competitiveness of the restaurant business and strengthen its competitive position in the market. The current trends in the development of the restaurant business, we can include: trends in the specialization of the restaurant offer; the creation of international restaurant chains; the development of a franchise network; the introduction of new computer technologies in the hospitality industry. In Ukraine, the restaurant business has not yet reached the international level and is only at the nascent stage. The dynamic development of this type of economic activity leads to the emergence of restaurant establishments of different types and price categories, which gives consumers the opportunity to choose such an institution in the restaurant sector that is most suitable for them according to all criteria.

Key words: restaurant business, trends, services, innovative technologies, trends, franchise.

JEL classification: L83 